\title{
Development of Garments by Textile Recycling Process using Various Combinations of Recycled Yarn
}

\author{
V. Yamuna ${ }^{1}$, S.Sudha ${ }^{2}$, P.Kandhavadivu ${ }^{3}$ \\ \{yamuna32@gmail.com ${ }^{1}$, ssd@fas.psgtech.ac.in ${ }^{2}$, hod.fashion@psgtech.ac.in ${ }^{3}$ \} \\ Department of Fashion Technology, PSG College of Technology $y^{1,2,3}$
}

\begin{abstract}
Recycling process in textile industry plays a significant role in order to move closer to a zero landfill society. Hence, the textile waste from garment industry is used in this project which was sorted out by color. These color sorting requires no re-dying process, saves energy and avoid pollutants. Garment cutting waste collected from industry was grinded into fibers and developed into yarn. This recycled yarn of 20's count, virgin yarn of cotton, viscose and polyester of same color and count is used for comparison. As the recycled yarn has less strength for producing fabric, the yarn was doubled with virgin yarns. To compare the properties of doubled yarn with virgin yarn, the virgin cotton yarn of 20 s count was also doubled with virgin viscose and polyester yarn. Then the woven fabrics were produced with twill weave structure from both the virgin and recycled doubled yarn. Fabric properties of all the samples were analyzed before constructing the garment. Due to the heaviness of the yarn as it is doubled, these fabrics are suitable for the construction of denim garments and hence the denim skirts were constructed from the woven fabrics. Combination of recycled cotton shows almost equal results as like the combination of virgin cotton \& polyester.
\end{abstract}

Keywords: Recycled yarn, Virgin yarn, Fabric properties, Denim, Yarn Doubling.

\section{Introduction}

The significance of reusing materials is progressively being perceived. More than 80 billion articles of clothing are delivered yearly, around the world. An expanding measure of waste is created every year from materials and their creation. For monetary and ecological reasons it's far important that as a ton of this loss as conceivable is reused in inclination to being discarded in landfill sites. In truth the charge of material reusing keeps on being particularly low.

On average, around ten million tons of material wastes are dumped each year. From the raw material production to the manufacturing of textile products, the industries rely heavily on our global finite resources such as land, water and energy. Hence textile and fashion industries play a major role as contaminating industry around the world after oil.

Textile waste can include fashion and textile industry waste, created during fibre, textile and clothing production, and consumer waste, created during consumer use and disposal. Almost a $100 \%$ of family textiles and apparel may be recycled, irrespective of great of condition. Recycling is a processing used to convert waste into new products to prevent waste of potentially useful materials, reduce the consumption of fresh raw materials.[1] Textile recycling is the method of reusing or reprocessing used clothing, fibrous material and clothing scraps from the manufacturing process. 
Recycling apparel and textiles advantages includes reduction of solid waste in landfills, a pathway for sustainability and environmentalism and reduces carbon footprint, creates financial improvement around the sector, converts waste merchandise into fee-added merchandise [2].

Textile recycling is for both, environmental and economic benefits. Textile recycling reduces the usage of chemicals and consumption of water for producing a garment by eliminating the dyeing process.

Textile waste is divided into two categories: pre-consumer waste and post-consumer waste. Pre-consumer waste contains by-products from the textile, fibre and cotton sectors that are remanufactured for use in automobiles, furniture, mattresses, and apparels etc [3]. Any type of garment made from manufactured textiles that the owner no longer wants and decides to discard is referred to as post consumer waste. According to the Council for Textile Recycling, 750,000 tones of textile waste (pre- and post-client) are recycled each year into new raw materials for the automotive, furniture, bed, coarse yarn production, home fittings, paper, and other industries.

A study on recycling the fabric scraps in apparel manufacturing industry has investigated the usability of recycled clothes. Ne $28,50 \%$ recycled cotton and $50 \%$ polyester yarns were produced from fabric scraps of a clothing company and compared with $\mathrm{Ne} 28,50 \%$ cotton \& $50 \%$ polyester virgin yarns. Single jersey materials were knitted with these yarns and garments had been sewn with these materials with the same construction stipulations. The physical residences of yarns, fabrics and garments had been compared with products that constituted of virgin substances. The experiment outcome indicated that there is now not an exotic change between recycled and virgin garments traits. From the result of this learns, it may be acknowledged that recycled garments constructed from material scraps can be utilized in apparel manufacturing enterprise [4].

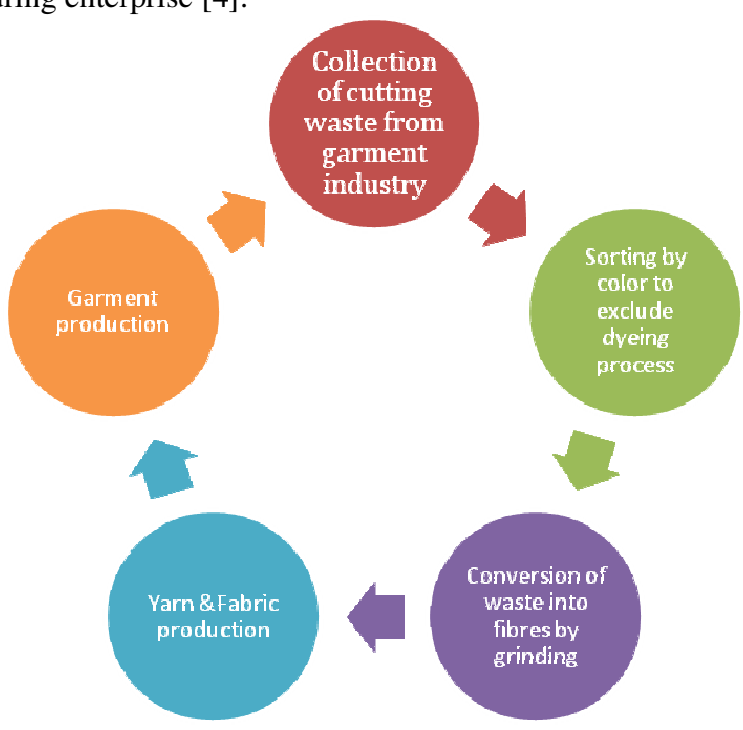

Fig.1. Garment production process by textile recycling 
The objective of this project is to produce woven fabrics from doubled yarns developed by combining recycled and virgin yarn and two virgin yarns respectively. All the yarn properties were analyzed and the fabric properties were also analyzed after weaving all the samples. Denim skirts were constructed finally from the woven fabrics and comparison made between virgin and recycled yarn garments.

\section{Materials}

A. Materials

In this study, 20s count of recycled yarn and virgin yarns of cotton, viscose and polyester were used.

\section{Methods}

\section{Doubling of yarn}

Single recycled yarn is doubled with recycled yarn, virgin polyester yarn, virgin viscose yarn in Two-For-One or TFO yarn twisting machine for strengthening and reducing the unevenness of single yarn. Two-For-One (TFO) is a two-stage process where the yarns are doubled and then twisted. Generally, the wax is applied to yarns before the first twisting stage in order to reduce the friction of yarns[5]. Blue and white colors were chosen in both virgin and recycled yarns for doubling in order to produce denim garment.

Yarn doubled samples

- Cotton yarn(blue) + Polyester yarn (blue)

- Cotton yarn(white) + Polyester yarn (white)

- Cotton yarn(blue) + Viscose yarn (blue)

- Cotton yarn(white) + Viscose yarn (white)

- Recycled cotton yarn (blue) + Polyester yarn (blue)

- Recycled cotton yarn(white)+ Polyester yarn (white)

- Recycled cotton yarn(blue) + Viscose yarn (blue)

- Recycled cotton yarn(white)+ Viscose yarn (white)

- Recycled cotton yarn(blue) + Recycled cotton yarn (blue)

- Recycled cotton yarn(white)+ Recycled cotton yarn (white)

Weaving

The doubled yarns were woven with the weave structure of 3/1 twill and GSM in the range of 254 to 282 with Ends per inch as 23 and Picks per inch as 19. Five different samples were woven and the yarns used as warp and weft for each samples are given in the table below:

TABLE I Warp and weft yarn selection for weaving

\begin{tabular}{|l|l|l|}
\hline Samples & Warp Yarn & Weft yarn \\
\hline
\end{tabular}




\begin{tabular}{|l|l|l|}
\hline Sample 1 & $\begin{array}{l}\text { Doubled recycled } \\
\text { yarn (blue) }\end{array}$ & $\begin{array}{l}\text { Doubled recycled yarn } \\
\text { (white) }\end{array}$ \\
\hline Sample 2 & $\begin{array}{l}\text { Doubled recycled and } \\
\text { polyester yarn (blue) }\end{array}$ & $\begin{array}{l}\text { Doubled recycled and } \\
\text { polyester yarn (white) }\end{array}$ \\
\hline Sample 3 & $\begin{array}{l}\text { Doubled recycled and } \\
\text { viscose yarn (blue) }\end{array}$ & $\begin{array}{l}\text { Doubled recycled and } \\
\text { viscose yarn (white) }\end{array}$ \\
\hline Sample 4 & $\begin{array}{l}\text { Doubled cotton and } \\
\text { polyester yarn (blue) }\end{array}$ & $\begin{array}{l}\text { Doubled cotton and } \\
\text { polyester yarn (white) }\end{array}$ \\
\hline Sample 5 & $\begin{array}{l}\text { Doubled cotton and } \\
\text { viscose yarn (blue) }\end{array}$ & $\begin{array}{l}\text { Doubled cotton and } \\
\text { viscose yarn (white) }\end{array}$ \\
\hline
\end{tabular}

Analysis of fabric properties

Physical properties

All the woven samples have been evaluated with the physical properties like GSM using GSM cutter and thickness with the help of thickness tester[6].

Mechanical properties

All the woven samples had undergone various mechanical tests like Pilling under the standard ASTM D4970[7], Dimensional stability under the standard AATCC Test method 135 -2010[8], Tensile strength under the standard ASTM D638 and Abrasion under the standard ASTM D4966[9].

Color fastness test

This test was carried out under AATCC test method 16.3:2012. Samples were exposed to light source under specified conditions. Xenon arc lamp (water cooled) is used and the samples were exposed for 24 hours where the exposed area is $30 \times 30 \mathrm{~mm}$. The color fastness to light was evaluated using Gray scale.

Garment construction \& Cost analysis

All the woven samples were used for constructing denim skirt. Five different skirts were developed and made visual comparison. Dyeing cost of yarn and fabric is totally reduced while using recycled yarn. Hence costing includes yarn procurement, doubling, weaving and garment construction. Cost analysis for each garment was calculated and obtained a difference in price of Rs.80 to100 lesser for the garments made from the combination of recycled yarn than with pure virgin yarn.

Results and Discussion

All the woven samples were tested for physical and mechanical properties and the results are discussed

Physical properties of fabric

GSM \&Thickness

GSM and Thickness is calculated for various combinations of woven fabric sample and the results are given below.

\section{TABLE II GSM \&THICKNESS OF FABRIC SAMPLES}

\begin{tabular}{|l|l|l|}
\hline Fabric & GSM & $\begin{array}{l}\text { Thickness } \\
(\mathbf{m m})\end{array}$ \\
\hline $\begin{array}{l}\text { Recycled cotton yarn + recycled } \\
\text { cotton yarn }\end{array}$ & 282 & 0.92 \\
\hline Recycled cotton yarn + polyester & 254 & 0.79 \\
\hline Recycled cotton yarn + viscose & 260 & 0.77 \\
\hline
\end{tabular}




\begin{tabular}{|l|l|l|}
\hline Cotton + Polyester & 263 & 0.85 \\
\hline Cotton + Viscose & 261 & 0.8 \\
\hline
\end{tabular}

More thickness is obtained for the combination of two recycled yarns when compared to others as the yarn count is coarser for recycled yarns. GSM is maintained almost even for all the samples except for recycled cotton yarn combination.

B. Breaking strength \& Elongation

Tensile strength and elongation is calculated for various combinations of woven fabric sample and the results are given below

TABLE III TENSILE STRENGTH OF FABRIC SAMPLES

\begin{tabular}{|c|c|c|c|}
\hline \multicolumn{2}{|c|}{} & $\begin{array}{r}\text { Breaking } \\
\text { strength(kgf) }\end{array}$ & $\begin{array}{c}\text { Elongat } \\
\text { ion } \\
\text { (mm) }\end{array}$ \\
\hline $\begin{array}{c}\text { Recycled yarn } \\
\text { recycled yarn }\end{array}$ & warp & 106 & 31 \\
\cline { 2 - 4 } & weft & 100 & 29 \\
\hline $\begin{array}{c}\text { Recycled yarn } \\
\text { polyester }\end{array}$ & warp & 140 & 44 \\
\cline { 2 - 4 } & weft & 115 & 38 \\
\hline $\begin{array}{c}\text { Recycled yarn+ } \\
\text { viscose }\end{array}$ & warp & 123 & 36 \\
\cline { 2 - 4 } & weft & 111 & 32 \\
\hline \multirow{2}{*}{$\begin{array}{c}\text { cotton }+ \\
\text { polyester }\end{array}$} & warp & 142 & 46 \\
\cline { 2 - 4 } $\begin{array}{c}\text { cotton }+ \\
\text { viscose }\end{array}$ & weft & 117 & 41 \\
\cline { 2 - 4 } & warp & 125 & 38 \\
\hline \multicolumn{2}{c}{ weft } & 115 & 36 \\
\hline
\end{tabular}

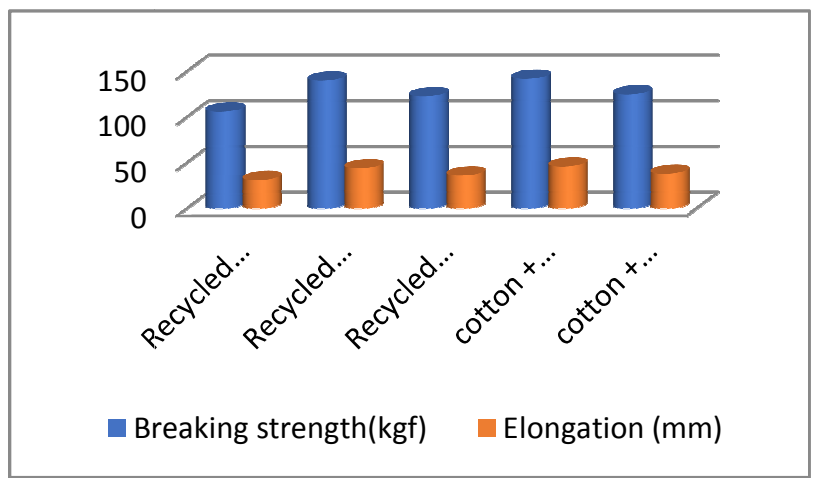

Fig.2. Tensile strength of fabric in warp direction 
The values of breaking strength tested for all the five woven samples indicates that more strength is obtained for the combination of yarns containing polyester in case of both recycled and virgin yarn. Combination of recycled yarn with polyester almost shows similar results with virgin yarn combination. As it known already that, synthetic fibre will have more strength when compared to natural and regenerated fibres.

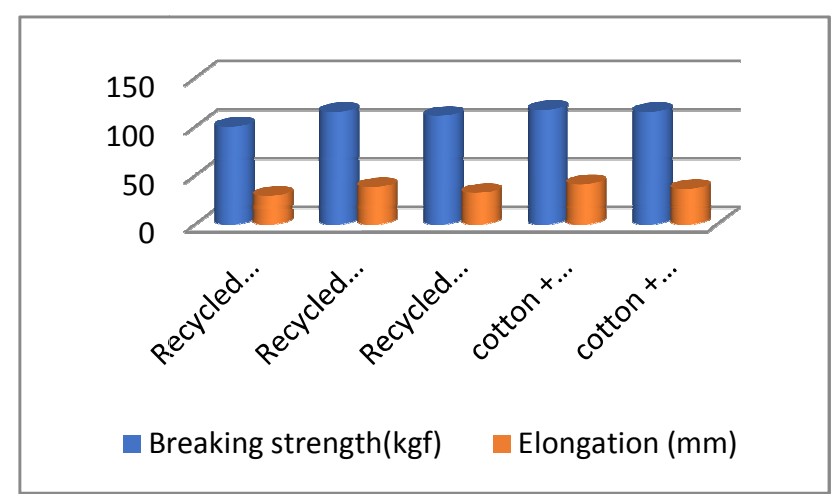

Fig.3. Tensile strength of fabric in weft direction

Elongation values are more for polyester and viscose yarn combination when compared to pure recycled cotton yarn combinations due to more thickness of fabric and cohesion between yarns.

C. Abrasion test

Abrasion test is calculated for various combinations of woven fabric samples by working with number of cycles as 6700 and the results are given in table below

TABLE IV WEIGHT LOSS \% OF FABRIC BY ABRASION

\begin{tabular}{|l|l|l|l|}
\hline Fabric & $\begin{array}{l}\text { Weight before } \\
\text { abrasion }(\text { gms })\end{array}$ & $\begin{array}{l}\text { Weight after } \\
\text { abrasion } \\
\text { (gms) }\end{array}$ & $\begin{array}{l}\text { Weight } \\
\text { loss \% }\end{array}$ \\
\hline $\begin{array}{l}\text { Recycled yarn + } \\
\text { recycled yarn }\end{array}$ & 0.420 & 0.400 & 5 \\
\hline $\begin{array}{l}\text { Recycled yarn+ } \\
\text { polyester }\end{array}$ & 0.420 & 0.410 & 2.38 \\
\hline $\begin{array}{l}\text { Recycled yarn + } \\
\text { viscose }\end{array}$ & 0.430 & 0.420 & 2.32 \\
\hline Cotton + polyester & 0.430 & 0.430 & 0 \\
\hline Cotton + viscose & 0.400 & 0.390 & 2.5 \\
\hline
\end{tabular}




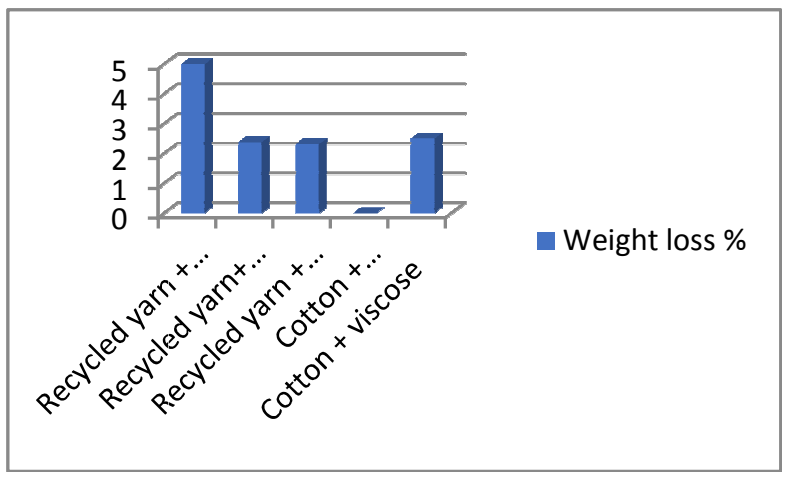

Fig.4. Abrasion strength of fabric samples

Weight loss percentage is noticed little higher for recycled yarn combination compared with other samples due to the coarser count of yarn and less tenacity.

E. Pilling test

Pilling test is calculated for various combinations of woven fabric sample with the number of cycles 5000 and the results are given below

TABLE V GRADING OF FABRIC FOR PILL FORMATION

\begin{tabular}{|l|l|}
\hline Fabric & Grade \\
\hline Recycled yarn + recycled yarn & 3 \\
\hline Recycled yarn + polyester & 4 \\
\hline Recycled yarn+ viscose & 4 \\
\hline cotton + polyester & 4 \\
\hline cotton + viscose & 4 \\
\hline
\end{tabular}

Pilling test results shows higher value of grade for all the combinations of recycled and virgin yarn except for combination of both recycled yarn. As the recycled yarn contains less tenacity and unevenness in yarn more pilling can be obtained for it when compared to other fabrics.

G. Dimensional stability

Dimensional stability is calculated for various combinations of woven fabric sample and the results are shown by plotting the graph. 


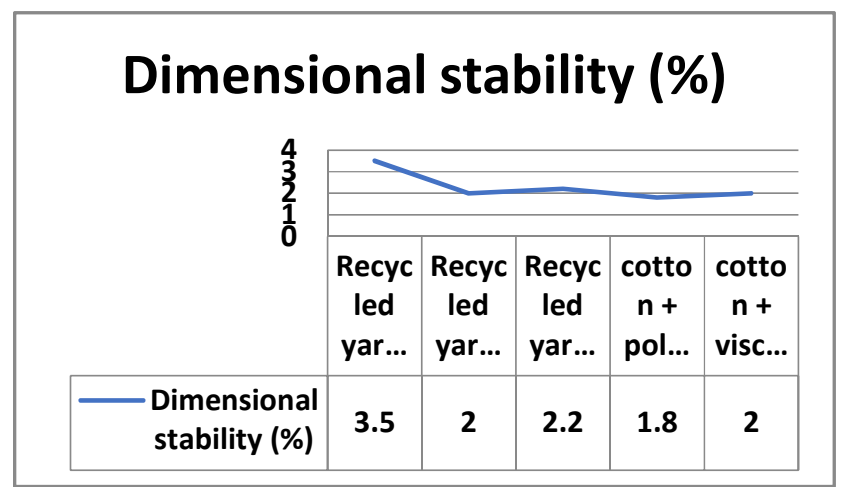

Fig.5. Dimensional stability of fabric samples

The recycled yarn combination with self shows higher stability due to heaviness of fabric when compared to other combinations.

F. Colour fastness test

Colour fastness test values of various combinations of woven fabric samples are given in the table shown below

TABLE VI COLOR FASTNESS VALUES OF FABRIC SAMPLES
\begin{tabular}{|l|l|l|l|l|l|}
\hline Multifibre & $\begin{array}{l}\text { Recycled Recycled } \\
\text { yarn } \\
\text { recycled } \\
\text { yarn }\end{array}$ & $\begin{array}{l}\text { Cotton + } \\
\text { yarn } \\
\text { polyester }\end{array}$ & $\begin{array}{l}\text { Recycled } \\
\text { polyester } \\
\text { yarn+ } \\
\text { viscose }\end{array}$ & $\begin{array}{l}\text { Cotton } \\
+ \\
\text { viscose }\end{array}$ \\
\hline Wool & 3 & 3 & 4 & 3 & 4 \\
\hline Acrylic & 4 & 4 & $4-5$ & 4 & $4-5$ \\
\hline Polyester & 4 & 4 & $4-5$ & 4 & $4-5$ \\
\hline Nylon & 3 & 4 & $4-5$ & 3 & 3 \\
\hline Cotton & 2 & 3 & 3 & 3 & 3 \\
\hline Acetate & 4 & 4 & $4-5$ & 4 & $4-5$ \\
\hline
\end{tabular}

Combination of recycled yarn shows medium color fastness when compared to virgin yarn combinations. As the recycled yarn does not undergo dyeing process when compared with virgin yarns, the fastness to color shows medium range of value.

G. Sample garment

Garments constructed as denim skirt from various combinations of fabric and the samples of recycled yarn combination and virgin yarn combination are shown in the figure below.

TABLE VII DENIM SKIRT DEVELOPED FROM VARIOUS COMBINATION OF YARNS

\begin{tabular}{|l|l|l|}
\hline S.No & Fabric & Garment \\
\hline
\end{tabular}




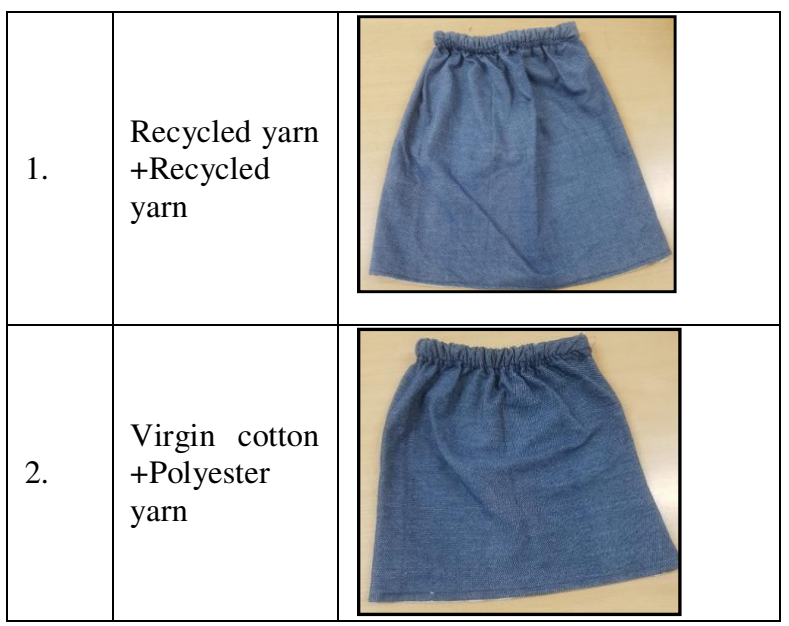

The samples shown in the figure above shows slight variation in the shade of color and the recycled yarn combinations shows almost similar shade of blue color when compared with virgin yarn combination.

\section{Conclusion}

When comparing all the woven sample properties, combination of recycled yarn and polyester yarn and virgin cotton and polyester stands best in all the properties like tensile strength, pilling, abrasion, colour fastness. Because of the higher strength, resiliency, resistance to most of the chemicals, quick drying, wrinkle resistance and easy care properties of polyester fibre [10], it provides better performance in combination with any type of yarn.

Hence it is observed from the results that using recycled yarn for garment production provides optimum support in all the properties. The main important point to be considered is it reduces the dyeing cost of fabric thus saves more amount of water, energy consumption, reduces man power etc are some of the important benefits of using recycled yarns. Hence recycled yarn can be used in combination with different types yarns in order to obtain the above said benefits.

\section{References}

[1] P.Senthilkumar, P.R.Yashikaa, "Recycled fibres" in Sustainable Innovations in Recycled Textiles, Springer Nature Singapore pvt.ltd, 2018.

[2] Gustav Sandin and Greg Peters, "Environmental impact of textile reuse and recycling - A review", Journal of Cleaner Production, vol.184, 353-365, February 2018.

[3] Chukwuebuka C. Oka, Christian N. Madu,Charles C. Ajaero ,Juliet C. Ibekwe and Chinelo A. Nzekwe, "Sustainable management of textile and clothing", Clean Technologies and Recycling, Volume 1, Issue 1 pp. 70-87,08 September 2021.

[4] kurtoğlu necef o., seventekin $\mathrm{n}$. and pamuk m, "A study on recycling the fabric scraps in apparel manufacturing industry”, Tekstil ve konfeksiyon, vol.23, pp.286-289, 2013. 
[5] Madan Regar, Sujit Kumar Sinha and Rabisankar Chattopadhyay, "Comparative assessment of EliTwist and TFO yarns", Indian Journal of Fibre and Textile Research, vol..43(4), pp.393-40, 2018.

[6] Anindya Ghosh and Prithwiraj Mal , "Testing of Fibres, Yarns and Fabrics and Their Recent Developments" in Fibres to Smart Textile, CRC Press, pp.221-256, August 2019.

[7] Rocco Furferi, Lapo Governi, Yary Volpe and Monica Carfagni, "Towards Automated and Objective Assessment of Fabric Pilling", International Journal of Advanced Robotic Systems,vol.11,November 2014.

[8] Jessie H. Chen-Y and JoAnn Emme, "Comparisons of fabric care performances between conventional and high-efficiency washers and dryers", Fashion and Textiles, vol.5:19, 2018.

[9] Ayub Nabi Khan, Sahabul Islam, Samee Shakir, Rahmat Ullah and Azizul Haque, "Study of Abrasion Resistance of Denim Fabric by Changing Shedding Mechanism, Fabric Construction \& Finishing Process (Singeing, De-Sizing), Current Trends in Fashion Technology and Textile Engineering, March 08, 2018.

[10] Praburaj Venkatraman, "Fabric Properties and Their Characteristics" in Materials and Technology for Sportswear and Performance Apparel, 1st Edition, CRC Press, 2015. 